\title{
GATHERING INFORMATION FOR THE KURANTY AND TRANSLATION TECHNIQUE AT THE COLLEGIUM OF FOREIGN AFFAIRS IN THE 1720s ${ }^{1}$
}

\author{
Ingrid Maier \\ Uppsala University (Sweden), Uppsala, Sverige, Sweden
}

Stepan M. Shamin

Russian Academy of Sciences, Moscow, Russian Federation

\begin{abstract}
This paper deals with the Kuranty (digests of foreign newspapers) during the 1720s. The authors' main focus is on the work of translators of the Collegium of Foreign Affairs on selection of materials for translation out of the newspapers sent to the Collegium by regular mail. The translation technique used for translating the foreign newspapers has also been analyzed. One of the conclusions consists in the fact that before translating newspapers, translators made notes in original texts thus marking the fragments necessary for translation, then they translated those fragments and passed the texts for reviewing to the heads of the Collegium of Foreign Affairs, who decided, which of the translated articles had to be presented to the Russian diplomats. During the 1720s, in contrast to the practice adopted in the $17^{\text {th }}$ century, the Kuranty was a tool for not only learning about foreign events, but also for keeping the European newspapers under observation. A comparison of the translation techniques applied for the "old" and the "new" Kuranty shows that these techniques had not changed a lot since the 1670s: in both cases the translators put aside irrelevant information. For instance, they left out entire sentences, if they were of low importance for the Russian officials, and so forth. Talking about the newspaper articles, which have been compared with their German originals, they may be characterized as more accurate than the Kuranty of the 1670s - almost every single word of the original German text had an equivalent in the translation. Generally speaking, the professional level of the translators - which was quite high already in the 1660s-1670s - had improved still more during the reign of Peter I.

Key words: The Kuranty, Collegium of Foreign Affairs, Peter I, 1724, translation technique.

Citation. Maier I., Shamin S.M. Gathering Information for The Kuranty and Translation Technique at the Collegium of Foreign Affairs in the 1720s. Vestnik Volgogradskogo gosudarstvennogo universiteta. Seriya 4 , Istoriya. Regionovedenie. Mezhdunarodnye otnosheniya [Science Journal of Volgograd State University. History. Area Studies. International Relations], 2018, vol. 23, no. 2, pp. 71-88. (in Russian). DOI: https://doi.org/ 10.15688/jvolsu4.2018.2.6
\end{abstract}

УДК (UDC) 94(47)“16/17”

Дата поступления статьи: 21.11.2017

ББК (LBC) 63.3(2)51

Дата принятия статьи: 29.01.2018

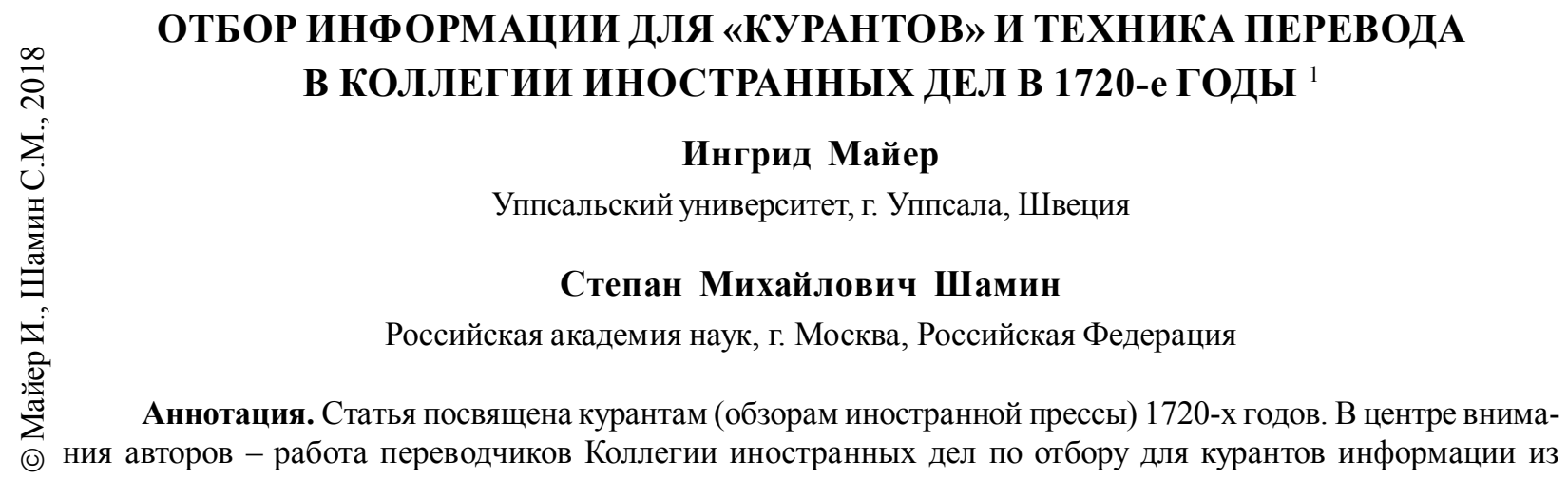


поступавших в коллегию по почте газет. Проанализирована также техника перевода публикаций иностранной прессы. Было установлено, что еще при чтении газет переводчики отмечали для себя на оригиналах то, что надо перевести, потом выполняли перевод, а руководители Коллегии иностранных дел решали, какие из переведенных сообщений требовали реакции со стороны русских дипломатов. В 1720 -х гг, в отличие от принятой в XVII столетии практики, через куранты не только узнавали о событиях за рубежом, но и наблюдали за европейской прессой. Сравнивая переводческую технику при составлении «старых» и «новых» курантов, нельзя сказать, что она сильно изменилась с 1670-х гг.: и тут, и там переводчики оставляли в стороне менее важную информацию; выпускали, например, целые предложения, не имеющие большого значения для российских правителей, и так далее. Если говорить конкретно о тех газетных статьях, которые проанализированы нами в сопоставлении с их непосредственными (немецкими) оригиналами, то их можно охарактеризовать как более «точные», чем куранты 1670-х гг., - почти каждое слово немецкого текста имело какое-то соответствие в переводе. Общий профессиональный уровень переводчиков (который был весьма высоким уже в 1660-1670 гг.) - в эпоху Петра І стал еще выше.

Авторы проводят совместное исследование по данной теме на протяжении более 8 лет, в равной степени работая как с источниковым материалом, так и с историографическим.

Ключевые слова: куранты, Коллегия иностранных дел, Петр I, 1724 г,, техника перевода.

Цитирование. Майер И., Шамин С. М. Отбор информации для «курантов» и техника перевода в Коллегии иностранных дел в 1720-е годы // Вестник Волгоградского государственного университета. Серия 4, История. Регионоведение. Международные отношения. - 2018. - Т. 23, № 2. - C. 71-88. - DOI: https://doi.org/ 10.15688/jvolsu4.2018.2.6

\section{Введение}

В последнее десятилетие опубликованы подробные исследования о переводах иностранных - прежде всего немецких и голландских - газет, так называемых курантах, выполненных в XVII в. в Посольском приказе для нужд царей и членов Боярской Думы [14, с. $15-$ 243; 29]. Куранты не были предназначены для более широкого распространения, а скорее рассматривались как своего рода «государственная тайна». Куранты XVII в. издаются с 1972 г. в серии с общим названием Becmu-Kуранть, причем для первых пяти выпусков (19721996 гг.) издавались исключительно русские переводы, а начиная с предпоследнего выпуска, вышедшего в 2008-2009 гг., издание русских текстов дополняется публикацией в современном наборе всех иностранных оригиналов, использовавшихся московскими переводчиками, - в той мере, в какой издателям удалось идентифицировать эти источники. (Конечно, найти все использованные когда-то иностранные оригиналы невозможно в связи с тем, что только маленькая часть самих иностранных газет сохранилась до наших дней.) Так, были изданы все иностранные оригиналы, обнаруженные для переводов 1656 г. и 1665-1670 гг. [14], а в одном томе с русскими переводами за 1671-1672 гг. даются найденные для того отрезка времени оригиналы [2].
На основе изданий оригиналов исследователи теперь могут судить о переводческой технике и качестве переводов, выполненных, в основном, в период 1665-1672 гг.; впрочем, в изданиях [2; 14] каждый найденный оригинал снабжен комментарием, в котором оценивается, в частности, качество перевода всех отдельных «микротекстов», то есть обычно газетной статьи, в редких случаях - целой переведенной брошюры непериодического характера.

В статье, опубликованной в 2011 г. (см. [15]), авторы данной публикации ввели в научный оборот комплекс подобных материалов 1720-х гг, не предназначенных для публикации в первой русской печатной газете Ведомости, которая увидела свет на стыке 1702 и 1703 годов. Сохранились эти материалы в двух московских архивах: незначительная часть осталась в Российском государственном архиве древних актов (РГАДА), где документы хранились изначально, а основная часть была передана в Архив внешней политики Российской Империи (АВПРИ). В нашей предыдущей работе мы особенно подробно исследовали обзоры европейской прессы, составлявшиеся в Коллегии иностранных дел за один год, а именно 1724-й. Было установлено, что между 1720 и 1724 гг. после перерыва примерно в двадцать лет дипломатическое ведомство России вернулось к практике составления курантов. Указать точную дату 
«возрождения курантов» оказалось невозможным из-за плохой сохранности некоторых единиц хранения, которые не выдаются исследователям по причине ветхости, а какая-то часть, возможно, вовсе и не сохранилась. Подчеркиваем, что в отличие от переводов изданий, делавшихся в Коллегии после 1702 г., тот комплекс материалов, который мы решили назвать «курантами» (и тем самим уподобили «старым курантам» XVII в.), не предназначался для публикации в газете Ведомости, хотя куранты и составлялись систематически, по крайней мере, с 1724 года. С этого времени сохранилось немалое количество «сводок», то есть компиляций, сделанных в один и тот же день из прибывших в тот день иностранных выпусков.

В нашей публикации 2011 г. основное внимание уделялось иностранным газетам, которые использовались в качестве источников для перевода [15, с. 94-103], а также вопросу о том, как русское правительство применяло полученные материалы в дипломатической практике [15, с. 103-105]. В данной работе мы поставили две главные цели: сначала дадим общую характеристику всех сохранившихся курантов 1720-х гг. (второй подраздел), потом остановимся подробнее на курантах 1724 г., наиболее ранних из доступных исследователям материалов (третий подраздел). На их основе мы провели своего рода пилотное исследование, позволяющее проиллюстрировать на конкретных примерах принципы отбора информации и технику перевода в Коллегии иностранных дел. Для этого мы сопоставили отдельные характерные русские переводы с их непосредственными немецкими оригиналами (четвертый подраздел).

\section{Куранты 1720-х гг: общая характеристика}

С начала 1720-х гг. в описи АВПРИ фиксируются дела с заглавием «Переводы из иностранных газет». Эти дела за 1721 и 1722 гг. содержат черновики для печатных Ведомостей. За 1720 и 1723 гг. тоже имеются дела примерно с таким же заглавием (дело № 37 за 1723 г. в описи обозначено «Переводы с иностранных ведомостей»), но они из-за ветхости не выдаются исследователям, так что трудно сказать, относятся эти материалы к переводам для газеты Ведомости или к «курантам ново- го типа». В связи с этим первый год, за который отложились переводы-куранты, доступные исследователям, - 1724 г., который мы по этой причине выбрали как основу для нашего «пилотного исследования». В АВПРИ также хранятся куранты за 1725-1727 и 1729-1731 гг. [713], а в РГАДА - за 1728 год.

Дадим краткую характеристику курантов 1725-1731 годов. Документы 1725 г. сшиты в книгу, общий объем которой составляет 147 л. [7]. На некоторых листах есть следы свертывания и сургучных печатей. Очевидно, что документы пересылали, скорее всего, по почте. При сшивании документов в книгу часть листов и сводок были перепутаны. Примерно треть первоначального объема материала не сохранилась, причем затраты касаются прежде всего первой половины года. Куранты следующего года (1726) ветхие и не выдаются исследователям [8]. Состояние курантов 1727 г. (98 л.) близко к материалам 1725 г., хотя сохранность несколько хуже [9]. Можно предполагать, что до наших дней дошло менее трети документов, в основном за январь-апрель, а также отдельные сводки за ноябрь-декабрь и первая за 1728 г. В книгу они были переплетены уже после того, как часть документов оказалась перепутанной, то есть первоначально каждая сводка хранилась отдельно. Куранты 1728 г., отложившиеся в РГАДА, имеют лучшую сохранность, чем документы предыдущих лет [10]. Вероятнее всего, до нашего времени дошли все сводки с 6 февраля по 30 декабря, что отразилось на общем объеме дела, состоящего из 525 л. Хорошая сохранность объясняется тем, что сводки подшивались помесячно вскоре после их составления.

Куранты 1729 г. помесячно не подшивались, однако значительных утрат не имеют [11]. Дело реставрировано: ветхие края обрезаны и подклеены прозрачной бумагой. Листы несут следы свертывания в пакет и нанесения сургуча. Документы этого года имеют ряд особенностей: к примеру, в 1729 г., кроме обычных курантов, Коллегия иностранных дел составляла еще и «курьезные» куранты, содержавшие познавательную и развлекательную информацию. Скорее всего, их читателем был юный император Петр II [31]. В этом же году на полях обычных курантов помещались 
пометы, в которых к иноязычным словам давались русские эквиваленты. Такая практика изредка встречалась и в другие годы, теперь же она стала довольно регулярной [30]. Куранты следующего года (1730-го) не выдаются из-за ветхости [12], материалы же 1731 г. имеют удовлетворительную сохранность [13]. За последующие десятилетия XVIII в. переводы иностранной прессы в АВПРИ сохранились отрывочно; мы их специально не изучали, и на настоящий момент затрудняемся сказать, продолжалось ли после 1731 г. систематическое составление курантов.

Изучаемые нами тексты 1720-х гг. в основном выглядят относительно аккуратно и хорошо читаются, хотя мы, вероятнее всего, в большинстве случаев имеем дело с переводческими оригиналами. Об этом говорят исправления, сделанные прямо по ходу написания текста. Чистовых экземпляров, по-видимому, не составлялось, поскольку на сохранившихся документах имеются пометы, связанные с использованием курантов в дипломатической работе. В этом отношении материалы 1720-х гг. существенно отличаются от курантов XVII столетия, когда русские переводы сначала появлялись в виде плохо читаемых (зато хорошо различимых по почеркам) черновиков, и лишь затем перебеливались для нужд русского правительства.

Если говорить об использовавшихся для составления курантов иностранных газетах, то за прошедшие 50 лет картина поменялась не особенно серьезно. В 1660-1670 гг. была очень популярна гарлемская газета. Кроме нее переводили материал из амстердамских и гаагских изданий. Немецкие газеты регулярно получали из Гамбурга, Берлина, Кенигсберга и Данцига; редко использовались издания из Бреслау, Штеттина и - уже совсем в порядке исключений - из Кёльна, причем из газеты, выпускавшейся там на латинском языке (см. [2; 14, с. 74-87]). В 1720-е гг, как и раньше, в основном переводили из газет, издававшихся либо в Голландии, либо на севере и востоке Германии. Например, в 1724 г. переводы делались по крайней мере из газет, выходивших в Гамбурге и соседнем городе Альтоне (ныне часть Гамбурга), Берлине, Бреслау, Кенигсберге, Лейпциге, Халле, Лейдене, Амстердаме и Гааге (подробнее об этих изданиях см. [15, с. 103]). Кроме того, в Коллегии иностранных дел в том же году получали - хотя и менее регулярно - газеты из Гарлема и Делфта. Гарлемские газеты в сохранившихся курантах 1724 г. упоминаются всего лишь один раз, а материалы из делфтских газет обнаружить нам вовсе не удалось. (Впрочем, в 16601670-е гг. именно гарлемская газета была одним из самых важных источников на нидерландском языке для составления курантов; см.: [14].) Однако, учитывая факт, что даже за «лучший» с точки зрения сохранности год для «новых» курантов, 1725-й, от изначально составленных обзоров сохранилось лишь примерно две трети, мы не можем с уверенностью утверждать, что переводы из делфтских газет так и не делались. Устойчивость информационных потоков за истекшие полстолетия определялась экономическими и политическими связями, структура которых со второй половины XVII столетия изменилась не особенно радикально; кроме того, можно предполагать, что на выбор газет для выписки влияло качество самих периодических изданий, которое тоже обычно было весьма стабильным в течение нескольких - или даже многих - десятилетий.

Сплошного выявления всех оригиналов 1720-х гг. нами не проводилось - это очень большая задача. Однако можно отметить, что после 1724 г. происходило постепенное расширение круга газет, из которых делались переводы. К примеру, в курантах 1727 г. видим переводы не только из газет, опубликованных в Гамбурге, Альтоне, Берлине, Бреслау, Кенигсберге, Амстердаме, Гааге, Гарлеме, но также из Липпштадта, Шиффбека (деревня в Голштинии, недалеко от Гамбурга), Франкфурта, Нюрнберга, Вены (то есть даже с юга немецкоязычной территории), Утрехта, Антверпена. В 1728 г. встречаются переводы статей, чьи оригиналы были опубликованы, в частности, в Лейпциге, Штетине, Дрездене, а годом позднее - Кёльне, Магдебурге, Гданьске (старые остались примерно как были и раньше).

Сравнивая источники для «старых» и «новых» курантов, можно отметить, что переводы все время делались из газет, отпечатанных в немецких землях и Нидерландах, однако в число последних теперь входили не только газеты на нидерландском, но и на французском 
языке. Между тем для курантов, составленных до 1672 г. включительно, оригиналов на французском языке не выявлено вообще ${ }^{2}$ [2; 14, с. 210], и среди сохранившихся в РГАДА иностранных газет франкоязычные газеты появляются лишь в 1693 г. [35, S. 218] ${ }^{3}$ (из Голландии). В 1720-е же годы перевод статей из франкоязычных голландских газет, особенно из лейденской газеты (популярно называвшейся «Gazette de Leyde»), стал обычным явлением. Из газет на других языках следует добавить издания на латыни, однако они как в XVII столетии, так и в 1720 -е гг. появляются крайне редко.

Уместно также сказать несколько слов о переводчиках. В 1720-е гг. составлением курантов, как и в XVII столетии, занимались переводчики внешнеполитического ведомства России. Поскольку «новые» переводы нередко подписаны (часто в виде помет типа «переводил N. N.»), мы знаем, что над сохранившимися переводами 1724-1725 гг. работали братья Борис и Петр Волковы, а также Франц Шевиус. В сводках 1725 г. кроме Б. Волкова и Ф. Шевиуса названы И.Ф. Келлерман, Косьма Хрипунов и Семен Иванов. В последующие годы упомянуты также Иван Панов, Адриан Позняков, Петр Никифоров, Моисей Арсеньев, Семен Мальцев, Алексей Протасов, Сергей Волчков, Василий Томилов, Борис Ларионов, Андрей Суровцов, Андрей Волков. Конечно, в каждый конкретный период над курантами работала небольшая группа переводчиков, - как, впрочем, и в XVII в., когда переводы были подписаны крайне редко, но мы знаем точно, что, к примеру, над курантами 1671-1672 гг. работали по крайней мере три переводчика: Андрей Виниус, Иван Тяжкогорский и Леонтий Гросс [2].

Остановимся кратко на том, как в Коллегии иностранных дел работали с готовыми курантами. На переводах 1720-х гг. встречается довольно много помет, к примеру, латинские буквы «NB» («nota bene»), которые должны привлекать внимание к конкретным строкам перевода, но также краткие указания типа «ответствовать», «опровергать» и отметки об их выполнении («ответствовано») и т. д. Смысл этих кратких помет становится понятным при обращении к более развернутым пометам-пояснениям со стороны сотрудников
Коллегии иностранных дел. К примеру, помещенная в сводке курантов от 5 мая 1728 г. статья из Нюрнбергской газеты с заглавием «Из Варшавы от 3 апреля» рассказывала о том, что время коронования Петра II в Москве перенесено, поскольку опасались, что ему может помешать бабушка императора (то есть Е.Ф. Лопухина); кроме того, сообщалось о том, что виновная осуждена пребывать в монастыре до самой смерти. В данном случае помета «Велеть опровергать» сопровождалась пояснением: в опровержении нужно сообщить, что государь задержался по пути в Москву из-за «худой зимы», а с бабушкой он находится в самых лучших отношениях [10, л. 173]. Сообщение о том, что престарелая и не имевшая сколько-нибудь значительной поддержки в среде русской знати Е.Ф. Лопухина могла выступить против Петра II, выглядит абсурдно: наоборот, единственным для нее шансом улучшить свое положение и приобрести влияние были хорошие отношения с внуком. Однако у незнакомого с русской действительностью иностранного читателя на основе этой заметки могло сложиться впечатление о нестабильности государственной власти в России. Подобные размышления, скорее всего, стали поводом для составления опровержения.

В некоторых случаях указывается, что опровержение отправлено «при публичных ведомостях» [10, л. 22 об.]. Копии этих «публичных ведомостей» также сохранились в АВПРИ. Они могли отправляться сразу всем зарубежным представителям, как, к примеру, в случае с документом от 11 ноября 1728 г.: «В 11 день отправлено ко всем при чюжестранных дворах обретающимся россииским министром опровержение на иностранные печатные куранты, с чего при сем копия прилагается под № 1» $[11$, л. 2]. Далее шел текст с официальным сообщением о смерти и погребении царевны Натальи Алексеевны, сестры Петра II. В данном случае, поскольку о смерти царевны писали во многих газетах по-разному, российские власти решили распространить по всей Европе «правильный» вариант этой новости, а не «опровергать» каждую из статей.

В другом случае, в декабре 1728 г., опровержение было отправлено лишь одному дипломату. Суть дела состояла в следую- 


\section{ОТЕЧЕСТВЕННАЯ ИСТОРИЯ}

щем: по донесению из Варшавы от чрезвычайного российского посланника Михаила Бестужева в гданьской газете появилось сообщение о том, будто бы в Швеции находился турецкий агент, который вел здесь (в Стокгольме) переговоры «по персицким делам». «Опровержение» направили российскому агенту во Гданьске, Георгию Эртману, вместе с копией газеты [11, л. 4a-4a об.]. В данном случае речь шла о событии, известном не из курантов, а из газеты, которую Бестужев специально прислал в Коллегию иностранных дел.

\section{Пилотное исследование: Куранты 1724 г. и их оригиналы}

В связи с тем, что оригиналы курантов 1720-х гг. сохранились в большом числе, мы решили провести «пилотное» исследование на основе переводов одного-единственного года, а именно 1724-го, и только с одного языка немецкого. Цель данного раздела - проиллюстрировать на конкретных примерах, как переводчики отбирали материал для курантов и как они справились со своей главной задачей: предоставить в руки правителей достоверные обзоры иностранных газет по интересовавшим их темам.

Интересующие нас куранты 1724 г. отложились в двух единицах хранения [5;6], каждая из которых содержит 31 лист большого формата. Первая в описи архива фигурирует как «Переводы на русский язык из иностранных ведомостей», вторая - «Выписки и переводы из иностранных газет». Первая содержит материалы за январь, февраль и июль, а вторая - за март, апрель, август, октябрь, ноябрь, декабрь 1724 года. Сложно сказать, по каким критериям они разделены на две отдельные единицы хранения. В обоих делах хронологическая последовательность комплектов сильно нарушена. Так, например, в начале первой находятся переводы (выполненные Борисом Волковым) из франкоязычной газеты из Лейдена, полученной 15 января; непосредственно за ними, на л. 3-4, имеются переводы, относящиеся к событиям июля 1724 г., а затем, на л. 5-7, опять находятся переводы из январских газет, на сей раз немецкоязычных [5].
Подавляющее большинство переводов 1724 г. сделаны либо из немецких газет, либо из франкоязычных, напечатанных в Голландии; более спорадически встречаются переводы из газет на нидерландском языке. Источники для некоторых текстов установить не удалось из-за неполной сохранности документов. С немецкого языка главным образом переводил Франц Шевиус, с французского - Борис Волков. Имя Петра Волкова имеется лишь в единственной сводке, под материалами из амстердамской газеты на французском языке. Во многих случаях автор перевода не указан. Кроме того, помимо однозначных помет «переводил» и «выписывал», встречается также не вполне однозначный вариант «свидетельствовал», а именно в связи с фамилией Шевиуса. Последнее может указывать на то, что Шевиус лишь проверял чью-то работу, а не переводил сам. С уверенностью можно сказать, однако, что большая часть переводов с немецкого языка выполнена Ф. Шевиусом (или по крайней мере под его контролем), а с французского - Б. Волковым. Всего в курантах 1724 г. мы смогли документировать подпись Бориса Волкова 13 раз, Петра Волкова - 1 раз, а Франца Шевиуса - 4 раза [5; 6].

Остановимся немного на этих переводчиках. Борис и Петр Волковы были сыновьями дьяка Посольского приказа Ивана Михайловича Волкова, игравшего на рубеже столетий заметную роль как в управлении приказом, так и в дипломатических миссиях. В частности, он был посланником в Венеции, резидентом в Речи Посполитой и послом в Священной Римской империи [3, с. 128, 154, 246257, 259, 262-263, 276, 337-338, 375].

Братья Волковы начали обучаться иностранным языкам в 1699 г. в Голландии, где вместе с отцом Иваном находились в свите А.А. Матвеева, «а велено им учится, где пристойно, латинского и немецкого и иных языков и наук» [4, с. 237]. Из голландской Гааги в 1701 г. Борис был отправлен в Париж, где выучил «половину грамматики по латыне, да и по галански говорить и писать»; в Париже он также изучал французский язык [4, с. 238]. Петр же (видимо, самый младший из трех сыновей Ивана Волкова) после того, как в Гааге изучал нидерландский, в 1701 г. вернулся с отцом в Москву, где доу- 
чивал этот язык в Немецкой слободе, а потом немецкий в школе на Новгородском подворье [4, с. 240]. В феврале 1711 г. его отправляли в Саксонию для обучения иностранным языкам; по его собственным словам, в письме царю от 2 февраля 1714 г., он в 1711 г. «работал... в Гановере при чрезвычайном посланнике г. Шлейнице ${ }^{4}$, потом в Париже при брате моем (должно быть, Григории. - И. М., С. Ш.), а ныне... при бароне Шаке ${ }^{5} \gg[4$, с. 241]. В своем же письме (написанном в Лондоне, где барон фон Шак был русским резидентом в 1713-1717 гг.) Петр Волков просит царя принять его на ставку переводчика в Посольской канцелярии, - видимо, с успехом, так как 8 марта того же года его взяли в штаб в качестве переводчика [4, с. 241]. Формального образования по переводу у братьев Волковых, очевидно, не было, и на самом деле специальный указ о целенаправленной подготовке переводчиков, подписанный самим императором, датируется только 1724 г. [20, с. 13].

Итак, братья Волковы, должно быть, знали несколько языков, когда они стали служить переводчиками в Посольской канцелярии. Впрочем, Борис Волков параллельно с составлением курантов отбирал и материалы для включения в газету Ведомости [19, с. 41, 75]. Лютеранин ${ }^{6}$ Франц Шевиус (Franz Schaevius, 16821753 [33]) принадлежал к числу немцев, которые находились на русской службе. Представляется, что он, будучи «русским немцем», блестяще знал оба языка, был настоящим и полным билингвом, о чем свидетельствует также качество его переводов (см. ниже). Совершенно закономерно мы встречаем его фамилию преимущественно после переводов с немецкого. Однако, по всей вероятности, он также знал нидерландский и французский языки: так, один раз его имя фигурирует под переводами из гаагских и гарлемских газет (там выходили газеты только на нидерландском языке, не на французском) [6, л. 10], а другой раз - в связи с переводом из лейденской газеты [5, л. 3-4].

\section{Куранты 1724 г. в сравнении с их иностранными оригиналами}

В данном разделе мы попытаемся показать на основе нескольких конкретных пере- водов отдельных газетных статей, что собой представляли «новые куранты» 1720-х годов. Каждый русский перевод приводится рядом со своим непосредственным (в нашей выборке - немецким) оригиналом.

Наш первый пример - перевод статьи из газеты Reichs Post Reuter, выходившей в городе Альтона близ Гамбурга ${ }^{7}$, а именно из выпуска № 144 за 1724 г. [36, л. 295-298]. Согласно помете на сохранившемся в АВПРИ экземпляре, газетный выпуск был получен 18 сентября 1724 года. Русская сводка курантов имеет надпись «Экстракть из печатных курантовъ полученныхъ в Санктъ Петербурхе сентября 18-г(о) дня 1724» [6, л. 7-8]. Дата составления данной сводки не указана, но мы можем исходить из того, что ее изготовили сразу после доставки газетного выпуска в Коллегию иностранных дел, - скорее всего, в тот же день. Переводчик также указал, каким газетным выпуском он воспользовался («В Алтонских № 144») и облегчил нам таким образом идентификацию нужного оригинала.

После этих вводных слов переводчик приступает к переводу самой статьи под заголовком «Petersburg/ vom 22. Augusti». В этом петербургском сообщении речь идет сначала о политических новостях, потом о научной деятельности профессора греческого языка Московской Еллино-греческой типографской школы Афанасия Скиады, который в 1723 г. издавал каталог греческих рукописей, хранившихся в Синодальной библиотеке [28]. (В 1724 г. этот каталог переиздали в Лейпциге; см. $\left[37^{8}\right]$.) В немецком оригинале петербургская корреспонденция от 22 августа помечена чертой на полях.

В русском переводе начало статьи, посвященное слухам о возможном браке вдовствующей курляндской герцогини (то есть Анны Иоанновны) с сыном ландграфа ГессенГомбурга, было отчеркнуто чертой, и на полях, напротив сообщения, стоит помета «ответствовать», выполненная рукой вице-президента Коллегии иностранных дел А.И. Остермана; ниже, другим почерком, добавлена помета «ответствовано». Скорее всего, речь шла о распоряжении Остермана об отправке опровержения и помете о том, что распоряжение выполнено. 
На полях напротив сообщения об описании рукописных книг А. Скиадой тоже имеется помета рукой А.И. Остермана: «были, нет в Синоду?» Под этой пометой имеется запись другим почерком: «списано и в Синод взнесено, а оттуда отповеди не было». Получается, сотрудников Коллегии иностранных дел эта часть газетной статьи заинтересовала с точки зрения вопроса, знает ли синодальное начальство о рекламируемых в немецкой газете научных начинаниях А. Скиады.

Ниже цитируется полный текст статьи. В нашей транскрипции русских текстов мы упрощаем орфографию, заменяя все вышедшие из употребления буквы их современными эквивалентами. Выносные буквы пишут- ся на строке и выделяются курсивом; другие сокращения раскрываются в круглых скобках. Пунктуация частично находится в рукописи (например, квадратные скобки), но, в основном, мы добавили пунктуационные знаки по современным правилам, чтобы облегчить понимание. Случаи мелкой правки, которые не привлекали нашего интереса в связи с техникой перевода, в наших транскрипциях не приводятся. Новый лист рукописи обозначается знаком «//».

Внутри газетной статьи ни в печатной газете, ни в рукописи нет абзацев; мы их ввели для того, чтобы было легче сравнивать соответствующие фрагменты на двух языках и ссылаться на какой-нибудь абзац в наших комментариях.

Перевод статьи из газеты Reichs Post Reuter (1724 z. № 144).

Пример № 1 Транскрипция русского и немецкого текстов

Из Петербурха от 22-г(о) августа.

Вдовствующая герцогиня курлянская в сихъ числехъ отсюда в свою резиденцию возвратилас, и ежели молве, которая пон(ы)не носится, верить, то она с стареишимъ принцомъ гессенгомбурскимъ сочетана будетъ.

Н(ы)не труждаются домъ генерала адмирала графа Апраксина, которои онъ ж герцогу голштинскому в квартиру очистил, богато убрать.

[Ко окончанию в прошедшихь курантахъ показанно и материи] его ц(а)рского величества отецъ, бл(а)женные памяти, одинъ в краткомъ времени $500{ }^{9}$ кодиков [или записных книгъ] древнеишихъ в России собрать повелел, между которыми одна особливо зело древняя от четырехъ евангелистовъ находится, которая славному манускрибту уподобляется, которой манускриптъ преж сего королю аглинскому патриархъ Александриискои Кириль Лукари подарилъ. // И точию в томъ не сходны, что в н(а)шем росииском литеры болши, нежели в ономъ, в протчем же во всемъ сходны.

И тако видимо, что собрание таких писемъ какую иную имее $m$ ползу, и ежели оное продолжится, то может быть и более таких изрядныхъ кн(и)гъ сыщется, и прежде показанноигосподинъ Шяда уповаетъ, что его ц(а)рское величество каталогъ [или описание] кн(и)гъ писменны $x$ умножитъ, и такую полную библиотеку ${ }^{10}$ греческихъ ауторовъ учередить изволить, что Европа еще не видела, а особливо ежели такие, которыхъ иначе получить невозможно, из другихъ библиотекъ за д(е)н(ь)ги списать велять
Petersburg/ vom 22. Augusti

Die verwittibte Hertzogin von Cuhrland ist dieser Tagen von hier wiederum nach deren Residence zurück gegangen/ und wann dem annoch gehenden Gerüchte zu glauben/ so wird dieselbe mit dem ältesten Printzen von Hessen Homburg vermählet werden.

Man ist jetzund beschäfftiget/ das Haus des General Admirals/ Grafen von Apraxin/ welches derselbe dem Herrn Hertzogen von Holstein/ um seine Wohnung darin zu nehmen/ eingeräumet hat/ auf das kostbahrste zu meubliren.

Gleichwie nun (zum Beschlu $\beta$ der im Vorigen fortgesetzten Materie) Ihro Czaarische Majestät Herr Vater gottseligen Andenckens/ allein in kurtzer Zeit $500 \mathrm{Co}-$ dices/ und zwar von denen ältesten in Rußland/ bringen lassen/ worunter insonderheit ein sehr alter Codex von denen 4 Evangelisten seyn soll/ welcher mit dem berühmten Manuscripto verglichen wird/ so vormahls dem König in Engelland/ von dem Partiarchen Cyrillo Lucari zu Alexandria/ geschencket worden/ indem sie nur darin unterschieden/ da $\beta$ unser Rußisches grössere Characteren hat/ sonsten aber in allen eins sind.

Und man denn siehet/ was die Collection solcher Schrifften für grossen Nutzen hat/ als durch deren Continuation vielleicht noch mehrere schöne Bücher vor den Tag kommen dürfften; also promittiret mehrgerühmter Schiada ihm auch/ daß Ihro Czaarische Majestät den Catalogum derer Manuscriptorum vermehren/ und eine so vollständige Bibliothec von Griechischen Autoren anschaffen werden/ als Europa wol noch nicht gesehen/ insonderheit wenn man auch diejenigen/ so man etwa nicht anders habhafft werden könte/ aus andern Bibliothequen für Geld wolte copiiren lassen; 
Окончание примера № 1

\begin{tabular}{|c|c|}
\hline $\begin{array}{l}\text { Между тем онъ самъ великую книгу писать, в } \\
\text { которо } u \text { регулы, ремарки и литеры изъяснить, } \\
\text { намеренъ, чемъ бы греческие пис(ь)ма толь наи- } \\
\text { способнее разуметь было можно, причем онъ } \\
\text { все } u \text { Европе показать хощеть, колико преизряд- } \\
\text { ныхъ греческих писменных книг Россиа имеетъ. } \\
\text { Без сумнения доволное иждивение ко оному } \\
\text { употреблено быть имеетъ. Господин Шяда пишет } \\
\text { зело ученымъ образом о техъ манускриптах и о } \\
\text { правописании, тако ж и какие в то } м / / \text { еще преж- } \\
\text { де, нежели печатание книгь изобретено, погре- } \\
\text { шении и неусмотрении учинились, такь что ни } \\
\text { одно } и \text { кн(и)ги нетъ, которая б з другими сходство } \\
\text { имеет, о чемъ он пример показуеть, и последи } \\
\text { важность древнихъ манускриптов со изъяснени- } \\
\text { емъ некоторыхъ причинъ утвердить трудится. }\end{array}$ & $\begin{array}{l}\text { Immittelst er selbst ein grosses Buch zu schreiben/ und } \\
\text { darin die Reguln/ Notas und Characteres an die Hand } \\
\text { zu geben vermeynet/ wodurch man sich in der Griechi- } \\
\text { schen Schreib-Art desto besser finden könne/ wobey er } \\
\text { dem gantzen Europa noch zu weisen gedencket/ wie } \\
\text { viele rare Griechische Manuscripta Rußland habe. Es } \\
\text { ist auch kein Zweifel/ es werde etwas rechtes darauf } \\
\text { gewendet werden. Der Herr Schiada schreibet sehr } \\
\text { erudit von denen Manuscriptis/ von der Art zu schrei- } \\
\text { ben/ und was dabey/ ehe die Buchdrucker-Kunst er- } \\
\text { funden/ für Fehler und grausame Schnitzer vorgegan- } \\
\text { gen/ so daß fast kein Codex zu bekommen/ der nicht } \\
\text { einer von dem andern etwas differire; wovon er auch } \\
\text { Exempel anführet/ und endlich die Nohtwendigkeit der } \\
\text { alten Manuscriptorum/ mit Allegirung dieser und jener } \\
\text { Ursachen/ zu behaupten fortfähret. }\end{array}$ \\
\hline
\end{tabular}

Комментарий. Легко убедиться в том, что переводчик (вероятнее всего, Франц Шевиус) хорошо справился со своей задачей. Единственную сколько-нибудь серьезную «ошибку» мы находим в разделе о греческих рукописях, по-немецки названных Codices (множественное число). Переводчик изначально перевел «500 Codices» cловосочетанием «500 книг», однако тут же вычеркнул слово книг и написал «500 кодиков», после чего добавил отсутствующее в немецком тексте объяснение (причем прямо в тексте, в квадратных скобках): «[или записных книгъ]». По нашему мнению, переводчик неудачно объяснил значение заимствованного с латинского языка слова. Значение оборота записная книга с XVIII в. не изменилось: Словарь русского языка ХVIII века для леммы записной дает значение 'служащий для записывания, записи' [23, с. 55]. Впрочем, ниже, в четвертом абзаце нашей транскрипции, немецкое слово Manuscript передано удачно: «каталогъ [или описание] кн(и)гъ писменных» (в немецком оригинале термины Codex и Manuscript употреблены как синонимы). Однако помимо ошибки в объяснении, что такое кодик, и саму форму заимствованного слова, выбранную переводчиком, нельзя признать удачной, так как он, исходя из множественного числа, Codices, образовал форму единственного числа кодик (вместо кодекс ${ }^{11}$ ), написав «500 кодиков». Можно предположить, что переводчик сам не был уверен в том, что введенное им слово кодик и его объяснение в скобках адекватно передает латинское codex, так как в следующий раз («worunter insonderheit ein sehr alter Codex ... seyn soll») он использовал числительное одна (вероятно, подразумевая одна книга): «между которыми одна особливо зело древняя... находится». Наконец, в третий раз, во фразе «so daß fast kein Codex zu bekommen», он все-таки вернулся к отвергнутому изначально переводу книга: «такъ что ни однои книги нетъ».

Переводчик сопроводил еще одно слово заключенным в квадратные скобки пояснением, а именно каталогъ, написав «каталогъ [или описание]»; в этом случае пояснение безусловно можно признать удачным. Слово каталог в принципе встречяется уже в Геннадиевской библии 1499 г., впрочем тоже с объяснением (см. цитату в Словаре русского языка XI-XVII вв. [22, с. 88]; второй пример в данном словаре датируется 1703 годом). Хотя Словарь русского языка XVIII века приводит довольно много примеров со словом каталог [25, с. 7], последнее в 1724 г. еще не было общеупотребительным, о чем как раз свидетельствует объяснение в нашем документе. Слово Manuscript, встречающееся в немецком тексте целых пять раз, переводчик в двух случаях переводит как «письменные книги» (удачно, по нашему мнению, для данного контекста), а в остальных использует транслитерацию немецкого слова (заимствованного с латыни), без какоголибо пояснения. С одной стороны, это слово очевидно уже употреблялось в русском языке (Словарь русского языка ХVIII века фиксирует его с 1721 г.; см. [26, с. 64]), но, с другой стороны, к концу длинного газетного сообения значение слова манускрипт уже просто ясно из контекста.

Стремление переводчика к максимальной точности в передаче оригинала можно проиллюстрировать на примере фразы «Bibliothec von Griechischen Autoren», которую он изначально вполне понятно перевел как «библиотеку греческую», но потом исправил на «библиотеку греческихъ ауторовъ». Фамилию греческого ученого Скиады (Афанасий Егорович Скиада, родом из Кефалонии) переводчик явно не знал; в газете его фамилия была написана в латинской форме, Schiada, а в переводе на русский она передана, как будто это нормальная немецкая фамилия, - Шяда. Вполне вероятно, что переводчик тут впервые встречал фамилию этого ученого, и догадаться, что он тут имеет дело с греческой фамилией, было трудно. Замечательно также, как он передал слово Schnitzer (в данном случае примерно 'грубая ошибка'): ему не удалось найти одного точного перевода, так он дал два перевода, которые вместе отлично передают значение немецкого слова: погрешения и неусмотрения. (Прилагательное grausam 'ужасный’ он не перевел.) 
Перейдем к нашему второму примеру. Комплект курантов начинается словами «Экстрактъ из печатныхъ курантовъ, полученных в Санктъ Петербурхе октября 18-г(о) дня 1724-г(о) году» и указанием на иностранный оригинал к данному сообщению: «В Алтонавскихъ № 162»; на полях, в центральной части листа, имеется помета «ответствовано» [6, л. 20]. Источником, совершенно верно, послужил выпуск № 162 альтонской газеты Reichs Post Reuter, тоже сохранившийся в АВПРИ [36, л. 331-334]. Снизу на выпуске - помета о дате доставки экземпляра: 18 октября. (Указания о получении выпусков на самих оригиналах и в русских переводах всегда совпадают.) Внимание переводчика привлекло сообщение из Голштинии, однако только в той мере, в какой внутри этой газетной статьи имелись новости из Петербурга: на газетном выпуске длинной вертикальной чертой помечена вся петербургская информация (включая маленький непереведенный фрагмент, который мы, однако, приведем в примечании № 12); кроме того, горизонтальной чертой обозначен точно конец переведенного фрагмента. Очевидно, переводчики сначала читали всю газету и помечали на полях (и иногда, как в данном случае, еще и среди строк), что интересно и что надо перевести, - в данном случае именно то, что мы включили непосредственно в пример № 2.

На нашем втором примере можно проследить, как переводчики Коллегии иностранных дел сокращали «избыточный» текст. В статье под заглавием «Aus dem Holsteinischen/ vom 12. Octobris» (в русском переводе XVIII в. - «Из Голштинии от 12-г(о) октября»), напечатанной на л. 333 об. - 334 об., сначала упоминаются письма из Копенгагена от 7 октября о том, как принцесса Шарлотта Амалия на днях праздновала свой день рождения. Это подробное сообщение, занимающее в печатной газете целые 30 строк, никак не интересовало переводчика; оно пропущено целиком и полностью (этот фрагмент в нашей транскрипции не приводится). Заслуживающей внимание считалась информация о России, и начало этого фрагмента переведено без особых сокращений. Однако в конце статьи переводчик пропустил более полстраницы немецкого текста, хотя речь все еще идет о России: не переведено, в частности, известие о том, что некоторое время назад газета сообщала, будто Петр хотел собрать все русские сословия в Санкт-Петербурге, чтобы им официально сообщить об уже назначенном им преемнике на троне. Согласно газетному сообщению, сначала планировалось положить этот документ в архив, но потом эта информация оказалась необоснованной, - тут налицо типичное опровержение газетной информации, распространенной опрометчиво. Поскольку, таким образом, газета сама опровергла информацию, напечатанную за какое-то время до написания нынешней статьи, с русской стороны, разумеется, не требовалось никакого дальнейшего опровержения, и можно было обойти газетное опровержение молчанием ${ }^{12}$. Впрочем, вполне возможно, что данное опровержение в альтонской газете было напечатано именно после реакции со стороны России; к сожалению, русские документы не могут подтвердить такое предположение, так как ныне доступный материал имеет слишком большие лакуны. После сообщения о прежней, оказавшейся неверной, информации длинная немецкая статья переходит на другие новости, не связанные с Россией и не отраженные в курантах.

В нашей транскрипции, как всегда, абзацы внутри газетной статьи добавлены нами (в частности, все пункты из списка предложений для мирного договора); в оригиналах этот список напечатан подряд, без новой строки для каждого пункта.

Наш третий пример относится к сводке курантов от 16 октября [6, л. 22-23]. Сводка начинается, как обычно, заглавием: «Экстрактъ ис печатныхъ курантовъ, полученныхъ в Санктъ Петербурхе октября 16г(о) дня 1724-г(о) году»; источник указан в виде «В Кенигсъберскихъ прусскои Фамы № 83». На этот раз из одного немецкого газетного выпуска, а именно № 83 [34, л. 319322] кенигсбергской газеты Königliche Preußische Fama ${ }^{13}$, для курантов был выбран материал из двух статей [34, л. 320-321]. Обе статьи помечены в оригинале чертой на полях. Мы приводим каждую газетную статью отдельно (примеры № 3 и 4). 


\section{Перевод статьи из газеты Reichs Post Reuter (1724 2. № 162). Транскрипция русского и немецкого текстов}

Из Голштиніи от 12 -г(о) октября.

Ис Петербурха уведомляютъ, что де его ц(а)рское величество от армии, стояще $и$ в Украине, двухъ генералов назначил к хану татарскому послать, чтоб оному мирно $и$ договор представить на следующихъ кондициахъ, а именно

1) Чтоб он за учиненные от его орды росиискимъ подданнымъ убытки 100000 рублев д(е)нгами заплатил;

2) чтоб грабежи свои весма пресекли, и росиискимъ купцамъ на Черном море торги имеющимъ в пути препятствия никакого не чинили;

3) чтоб своимъ людемъ накрепко запретилъ, дабы впре $\partial$ никто из них за границею на земли царско $u$ не явился, и за то преступление штрафовать другимъ в образецъ;

4) когда // Росиа с которымъ либо двором воину возимеетъ, в которую ханъ татарско $и$ по притчине соседствва или по другимъ резонамъ справедливо вступить имеетъ, чтоб онъ тогда соде $p$ жал неутралите

5) чтоб велель посланнику своему при росииском дворе постоянно быть, також де и ц(а)рь такого $ж$ росиского министра в Баехфареуме всегда содержать намерен;

6) чтоб ц(а)рю столько лошаде $u$, сколко онъ при начато $u$ воине в свою кавалерию потребуетъ, из своих земель отправить велел;

7) чтоб ц(а)ря призналь императоромъ и тако $u$ титул в свои $x$ посылающи $x$ ся к нему грамота $x$ всегда употреблял.

Однако ж с стороны росиискои сумневаются, чтоб ханъ на оныхъ утвердился.
Aus dem Holsteinischen/ vom 12. Octobris. [...]

Sonsten will aus Petersburg verlauten/ wasmassen Ihro Majestät der Czaar 2 Generals von der in der Ukraine stehenden Armee denominiret hätte/ eine Tour zu dem Tartar Han zu thun/ um selbigem einen Frieden auf folgende Conditiones vorzuschlagen/ nemlich

1) Den durch seine Horden denen Rußischen Unterthanen zugefügten Schaden mit 100000 Rublen baar zu vergüten.

2) Von dessen Raubereyen gäntzlich abzustehen/ und die nach dem schwartzen Meer handelnde Rußische Kauff-Leute auf ihrer Reise nicht zu turbiren.

3) Seinen Leuten ernstlich zu verbieten/ auf Czaarischem Grund und Boden ins künfftige sich mehr finden zu lassen/ oder widrigenfalls dieselben exemplarisch zu bestraffen.

4) Wenn Rußland mit einem oder anderen Hofe in Krieg verfiele/ worin der Tartar Han/ wegen der Nachbahrschafft oder aus andern Raisons/ sich billig impliciren müste/ sich neutral zu halten.

5) Einen beständigen Envoye an dem Rußischen Hofe residiren zu lassen/ wie denn einen dergleichen Minister der Czaar zu Baechsareum stets zu halten gedächte.

6) Dem Czaarn so viel Pferde/ als er/ bey einem entstehenden Krieg/ zu Remontirung seiner Cavallerie/ nöhtig/ aus seinen Ländern abfolgen zu lassen; und 7) den Czaar für einen Kayser zu erkennen/ und diese Titulatur in seinen an ihn ablassenden Briefen allemahl zu beobachten:

wiewol man Rußischer Seits zweifelte/ da $\beta$ der Han solches eingehen werde; \{es wäre denn/ da $\beta$ seine Schwachheit/ die ihn jetzo zu Bette hielte/ ihn/ eines und das andere einzugehen/ obligirte. $\}[\ldots]$

Комментарий. Текст переведен без особых сокращений, и в результате русский читатель получает версию, по крайней мере не менее понятную, чем исходный немецкий текст. Непереведенным осталось последнее немецкое предложение последнего абзаца о слабости (крымского) хана. (В нашей транскрипции мы включили этот фрагмент в фигурные скобки.) Интересно проследить, как переводчик обращался с заимствованными с латинского и французского языков словами в немецком тексте. Conditiones 'условия’ в первом, вводном, абзаце он переводит таким же русским заимствованным словом - см. его фразу: «на следующих кондициахъ» (слово кондициа зафиксировано с 1703 г.; см. [25, с. 131]). Таким же образом он поступил со словом Raisons 'причины' в абзаце под пунктом 4: «аus andern Raisons» - «по другимъ резонамъ», а также Cavallerie под пунктом 6 («в свою кавалерию потребует») ${ }^{14}$. В случае с немецкой фразой sich neutral zu halten (под пунктом 4) он также использовал новое русское заимствованное слово, причем он - очень удачно - изменил синтаксис немецкой конструкции, употребив русское словосочетание с глаголом и существительным (вместо прилагательного), - содержать неутралитет. (В Словаре русского языка ХИІІ века слово неутралитет отмечается с 1735 г., прилагательное нейтральный - с 1702 г.; см. [27, с. 203204].) В других случаях - а именно тех, когда подходящего русского заимствованного слова не было-он, совершенно справедливо, передал иностранное слово понятной русской фразой: «nicht zu turbiren» 'не препятствовать' - «препятствия никакого не чинили» (под пунктом 2); «ехеmplarisch (zu bestraffen)»-«(штрафовать) другимъ в образецъ» (пункт 3). Ни одно из этих решений не вызывает критики. Переводчик, очевидно, не узнал под испорченным в немецкой газете написанием Baechsareum (пятый пункт) столицу Крымского ханства, Бахчисарай (нормальное немецкое написание-Bachtschisaraj), написав Баехфареум. Он примерно транслитерировал «немецкую» (латинизированную) форму, причем перепугал букву «s длинный» в немецкой готике (n) с буквой $f(\mathrm{f}),-$ что, впрочем, никогда не случается, когда он понимает немецкое слово. Поскольку ошибку тут допустил автор газетного сообщения (или наборщик немецкой газеты), ее не следует считать серьезным проступком переводчика. 


\section{ОТЕЧЕСТВЕННАЯ ИСТОРИЯ}

В самом начале газетной статьи переводчик пропустил 15 строк немецкого текста, не касающихся России (например, о заразной болезни в Турции). Очевидно, что переводчик данного сообщения из Константинополя не ставил перед собой задачу составлять точный и почти дословный перевод даже только той части, в которой речь идет о российских делах. Уже в первом абзацеописание хода событий сильно упрощено: не упомянуто, что аудиенция российского министра имела место у султана («bey dem Groß-Herrn»; впрочем, эта информация вытекает из дальнейшего текста) и что российского резидента, согласно традиции, представил государственный эфенди (примерно 'министер иностранных дел'). (Мы включили непереведенный фрагмент немецкого текста в фигурные скобки.) Очевидно, переводчика заинтересовало не то, что было как обычно, как всегда, а те подробности, которые отличались от «нормальных» аудиенций иностранных послов в Константинополе. Так, статья помечена чертой на полях, но не вся статья, а черта начинается возле слов «und ist bey dieser Gelegenheit observiret worden», то есть помечен текст начиная со второго абзаца нашей транс- крипции, - а именно начиная с этого места в переводе больше нет никаких существенных сокращений. Наиболее важной информацией для переводчика было то, что слуги российского резидента были вынуждены дождаться конца аудиенции «in dem Vorhofe» (в русской версии - «в сенях»), в то время как в случае других аудиенций с иностранными послами слуги на время аудиенции пускались «в переднюю султанскую» («in die Anti-Chambre des Sultans»); кроме того, при других аудиенциях выстраивались в два ряда пребывающие на месте знатные министры перед приемной султана, приветствующие таким образом иностранного посланника, но и эта традиция в данном случае не соблюдалась, а, как было сказано в первом предложении второго абзаца, на приеме присутствовала всего лишь очень маленькая группа людей.

В русской рукописи на полях напротив этой статьи имеется помета рукой А.И. Остермана: «ответствоват(ь) что ...» (далее одно слово не читается); ниже другим почерком помечено: «ответствовано». Должно быть, помета Остермана относится к сообщению о «дискриминации» российского резидента.

Перевод статьи из газеты Reichs Post Reuter (1724 2. № 83).

Пример № 3 Транскрипция русского и немецкого текстов

\begin{tabular}{|c|c|}
\hline 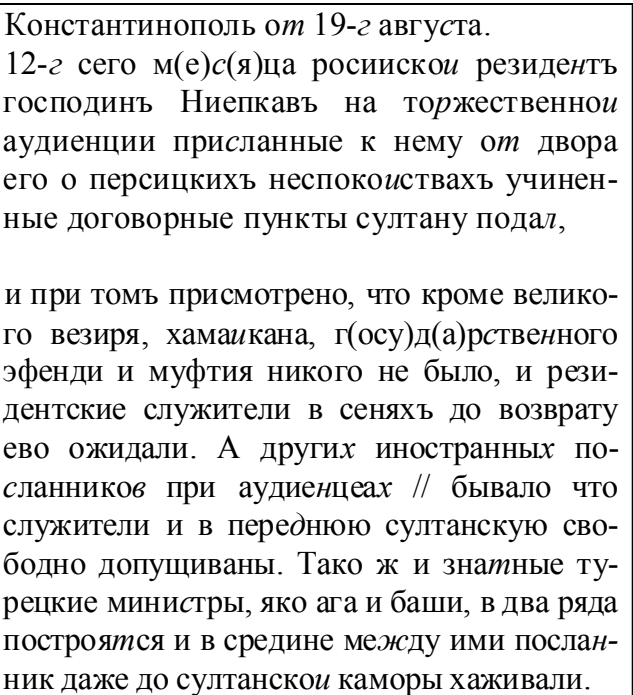 & $\begin{array}{l}\text { Constantinopel vom 19. August [...] } \\
\text { Am 12. dieses ward der Rußische Resident Herr Niepcaf } \\
\text { zur solennen Audientz \{bey dem Groß-Herrn admittiret, } \\
\text { und hat der Reichs-Effendi denselben gewöhnlicher mas- } \\
\text { sen introduciret.\} Es hat dieser Herr die von seinem Hofe } \\
\text { ihm zugeschickte und wegen der Persischen Troublen ge- } \\
\text { troffene Accommodements-Puncta dem Sultan überreichet, } \\
\text { und ist bey dieser Gelegenheit observiret worden, wie ausser } \\
\text { diesem Gro } \beta \text {-Vezier dem Chamaican, Reichs-Effendi und } \\
\text { Muffti, sonst kein Mensch zugegen gewesen, und haben die } \\
\text { Bediente des Residenten in dem Vorhofe bi } \beta \text { zu seiner Zu- } \\
\text { rückkunfft wahrten müssen, welches bey Ertheilung der Au- } \\
\text { dientz an andere frembde Gesandten mehrmahlen practisiret } \\
\text { worden, da die Bediente so lange in die Anti-Chambre des } \\
\text { Sultans frey paßiren mögen, und sonsten auch die vornehmste } \\
\text { Türckische Ministers, als die verhandene Aga und Bassen } \\
\text { sich in zwey Reyhen rangiret, zwischen welchen dann die } \\
\text { Gesandte bi } \beta \text { ins Sultans Gemach gegangen. }\end{array}$ \\
\hline
\end{tabular}

Комментарий. С точки зрения языка можно констатировать, что перевод, как обычно, в принципе выполнен качественно. Переводчик нашел удачные соответствия всем заимствованным словам немецкого оригинала, причем он использовал либо те же слова также и по-русски (аудиенция и все турецкие слова типа султан, везирь, хамайкан, эфенди, муфтий, ага, бама ${ }^{15}$ ), либо подходящие исконные русские слова: Troublen - неспокойства; Accommodements-Puncta - договорные пункты. Однако можно отметить и неточность: переводчик не выразил превосходную степень прилагательного «die vornehmste Türckische Ministers» ('cамые знатные турецкие министры'), написав просто «знатные турецкие министры». С синтаксической точки зрения не совсем 
удачным получилось предложение «А других иностранных посланников при аудиенцеах...»; с другим порядком членов предложений, «А при аудиенцеах других иностранных посланников...», синтаксис этого предложения получился бы более понятным. Но как упомянутое мелкое упрощение, так и синтаксическую неточность можно простить переводчику, несомненно работавшему в условиях постоянной нехватки времени.

Наш последний пример, № 4, относится к той же сводке курантов, что и предыдущий; немецкий оригинал для данного перевода, под заглавием «Nieder-Elbe vom 6. Octobr.» тоже взят из той же кенигсбергской газеты, что и тот пример (Нижняя Эльба - это регион Гамбурга). Между сообщениями из Константинополя и с Нижней Эльбы были пропущены три статьи немецкого оригинала, а именно новости из Фонтенбло, Парижа и Лондона.

Газетная статья в оригинале помечена на полях, но, как и в примере № 3, не вся статья: не помечено одно предложение, которое так и не было переведено (в нашей цитате мы привели непереведенное предложение в фигурных скобках). Переводчик, видимо, в данном случае сначала для себя пометил в оригинале совершенно точно, какие фрагменты следует перевести, а потом приступил к делу, опираясь на предварительные пометы.
Примечательно, что не переведен третий абзац немецкого текста (поставленный нами в фигурные скобки), хотя в нем речь идет о российских делах, а именно о том, что сняли паруса и т. д. с самых больших кораблей в Кроншлотте («Cronschlott», ныне Кронштадт), - подразумевается, перед наступающей зимой. Тем самым из последнего абзаца русской версии не становится ясным, что именно российские корабли «от жестоких ветровъ не мало $и$ ущербъ получили». Должно быть, об этом и без того знали как переводчики, так и те люди, для которых обзоры иностранных газет были предназначены, и информация о значительном ущербе российских кораблей была включена в куранты исключительно с точки зрения того, что этому событию уделяла внимание кенигсбергская газета. В русской рукописи нет никаких помет о том, что надо «ответствовать»; видимо, Остерман в данной статье не нашел ничего, что потребовало бы какихлибо дипломатических шагов.

\section{Перевод статьи из газеты Reichs Post Reuter (1724 2. № 83). Транскрипция русского и немецкого текстов}

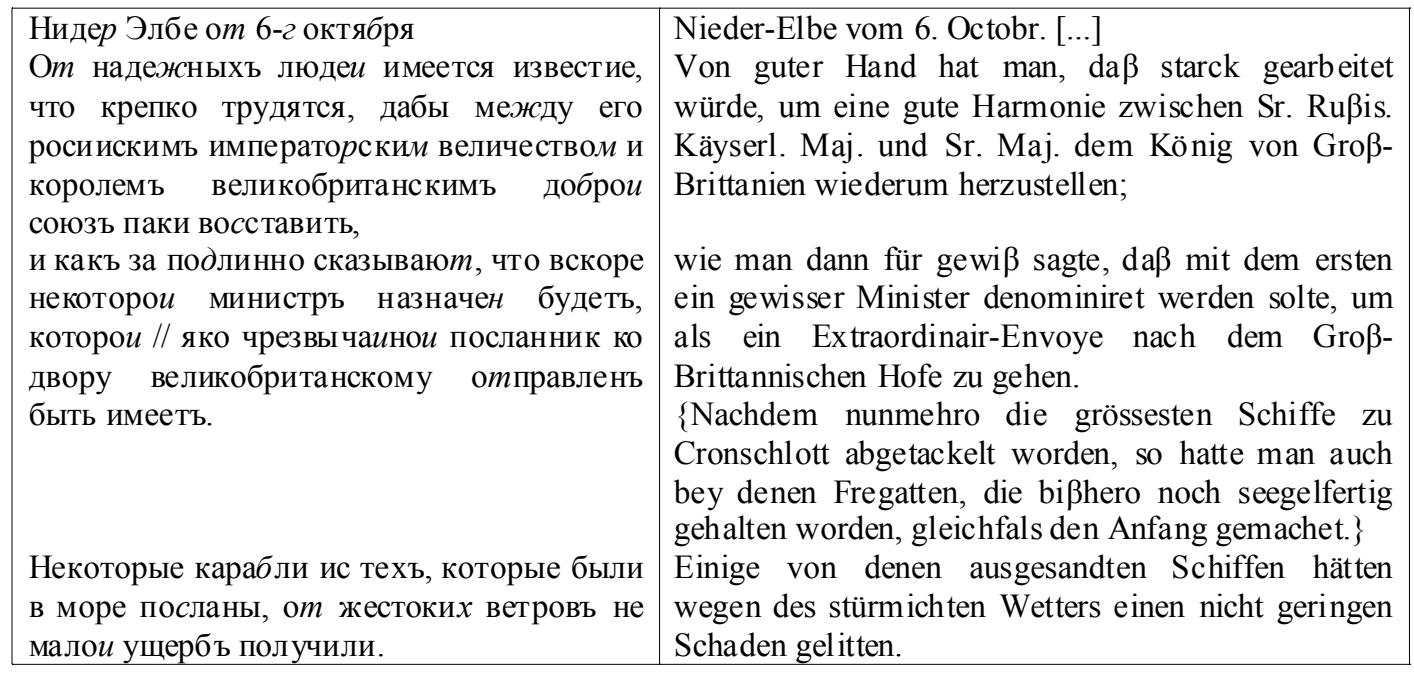

Комментарий. С лингвистической точки зрения примечательно, что переводчик не употреблял вариант «Нижняя Эльба» («Nieder-Elbe»), который встречается в курантах предыдущего века (см., например: [1, c. 499, $\left.501{ }^{16}\right]$ ) и также соответствует современной практике, а использовал транслитерацию топонима, «Нидер Элбе», - очевидно, мы тут имеем дело просто с личным предпочтением данного переводчика. Он отлично перевел газетный штамп XVII-XVIII вв. «Von guter Hand hat man ...», написав «От надежныхъ людеи имеется известие», и в остальной части перевода мы тоже не нашли никаких погрешностей. Как обычно, переводчик отлично справился с заимствованными словами (которых в данном фрагменте имеется только два): Harmonie - coюзъ; Extraordinair-Envoye - чрезвьччайной посланник. 


\section{Результаты}

Подведем итоги. При сравнении курантов 1720-х гг. с подобными текстами 1660 1670-х гг. нами были отмечены как сходства, так и некоторые различия (см. также [15, особенно с. 92-94]). И в том, и в другом случае переводы делались не для публикации, а для нужд внешнеполитического ведомства. Основное различие состоит в изменении их функции: если для русских правителей XVII в. куранты были важным источником политической информации и переводились корреспонденции из всей Европы, на самые разные темы, то в 1720-е гг. переводчики часто обращали внимание на такие газетные сообщения, в которых речь шла о российских делах. При этом только маленькая часть из «важных» сообщений имела название «Петербург» в своем заглавии; нередко о событиях, касающихся России, сообщалось под иным заглавием, например, «Из Голштинии» (наш пример № 2), «Константинополь» (пример № 3) или «Нидер Элбе» (№ 4). Таким образом, переводчики должны были прочитать газетные выпуски целиком. При чтении они отмечали для себя на оригиналах, что надо перевести, а руководители Коллегии иностранных дел решали, какие из переведенных сообщений «требовали» той или иной реакции со стороны русских дипломатов, - как правило, отправки опровержений либо в адрес определенной газеты, либо иностранного двора. В XVII в. использованные в Посольском приказе газетные выпуски не содержали информации о переводимых фрагментах; как максимум, на них имеются пометы типа «Переведены», или какаято статья была помечена крестиком, но чаще всего на использованных оригиналах нет никаких помет. На трех из проанализированных нами переводов имелись деловые распоряжения Остермана (подобных распоряжений на курантах XVII в. мы не находим), что свидетельствует об изменившейся функции курантов, - очевидно, что в 1724 г. с курантами работали более динамично, чем в 1670 гг.: при помощи курантов теперь не только узнавали о событиях за рубежом, но и наблюдали за европейской прессой (см. также [15, с. 105-106]).

Изменение назначения курантов повлияло также на их структуру: в 1720-е гг. пере- водчики начали довольно точно фиксировать «выходные данные» каждой переведенной газетной статьи, то есть они указывали место печати, иногда даже название газеты, и хотя и не вполне систематически - номер соответственного выпуска. Так дипломатам было легче найти адресата претензий (в тех случаях, если реакцию надо было отправить издателю газеты); побочным эффектом стало, что тем самым также облегчилась задача нынешних исследователей найти иностранные оригиналы. В курантах XVII в. подобная информация не давалась; обычно переводчики указывали как максимум язык, с которого были сделаны переводы, и выявить оригиналы можно было только путем сравнения с русскими переводами всех вообще газет, выпускавшихся на севере и востоке немецкоязычной территории и в Голландии.

Сравнивая переводческую технику при составлении «старых» и «новых» курантов, нельзя сказать, что техника сильно изменилась с 1670-х гг.: и тут и там переводчики оставляли в стороне менее важную информацию - выпускали, например, целые предложения, не имеющие большого значения для российских правителей. Кроме того, как в курантах XVII в., так и в 1720-е гг. практиковалось объяснение иностранных слов или реалий, и практика отличалась только в деталях: в то время как переводчики Посольского приказа в основном делали пояснения в виде помет на полях столбцов, мы могли показать, что такие объяснения в наших примерах давались в квадратных скобках прямо в тексте. Впрочем, для XVIII столетия объяснение неизвестных слов или реалий было обычной практикой, которая имела место, к примеру, и в «Примечаниях к Санкт-Петербургским Ведомостям» (см. [17]).

Имеются и другие различия. Так, в 1670-е гг. переводчики нередко под одним заглавием (например, «Варшава от 15 февраля») объединяли материал из разных газетных статей (в оригинале имевших либо ту же дату, либо близкую); такие случаи мы в проанализированных нами материалах 1724 г. вовсе не встречали. Кроме того, в курантах 1670-х гг. переводчики регулярно выпускали отдельные мелочи (указания фамилий, географических названий, обстоятельства вре- 
мени, причины и т. д.); в этом отношении переводы 1724 г., проанализированные нами в сопоставлении с их непосредственными оригиналами, можно охарактеризовать как более «точные», чем куранты 1670-х годов. Как мы можем убедиться на основе приведенных примеров, почти каждое слово немецкого текста имело какое-то соответствие в переводе. Если один из авторов данного исследования при работе над шестым томом «Вестей-Курантов», сравнивая тексты 16601670 гг. с переводами более раннего времени, отмечал, что «общая лингвистическая подготовка переводчиков за какие-то 3040 лет значительно улучшилась» [14, с. 190], то теперь можно констатировать, что положительная динамика сохранилась и позднее. В нашей - правда, весьма ограниченной выборке текстов, изученных в сопоставлении с оригиналами, мы смогли обнаружить всего лишь одну сколько-нибудь серьезную ошибку - неправильное толкование слова Codex. Однако здесь переводчику пришлось столкнуться с весьма специфической научной информацией, не встречающейся в повседневной дипломатической практике. Текст о научных начинаниях А. Скиады скорее напоминает научно-популярные материалы издававшихся с 1728 г. «Примечаний» к «Санкт-Петербургским Ведомостям», которые изначально составлялись на немецком языке, а затем переводились на русский ${ }^{17}$. То есть в связи с кодексом речь шла не столько о знании языка, сколько об уровне общего образования переводчика, широте его кругозора.

Для настоящей работы мы провели своего рода пилотное исследование на основе весьма ограниченного материала; в связи с этим наши наблюдения в данный момент еще носят предварительный характер. В целом же куранты, изготовлявшиеся в Коллегии иностранных дел в последние годы жизни Петра Великого, а также в годы правления его ближайших преемников, имеют большие перспективы для дальнейшего исследования. И более того: нам кажется, что стоило бы издавать куранты 1720-х гг. параллельно с их иностранными источниками, бо́льшая часть которых сохранилась в российских архивах.

\section{ПРИМЕЧАНИЯ}

1 Авторы благодарят Юбилейный фонд Шведского государственного банка (Riksbankens jubileumsfond, проект № RFP120055:1), поддержка которого помогла И. Майер ездить в командировки в Россию.

${ }^{2}$ Куранты за 1673 г. и далее не изданы; идентификация иностранных оригиналов для них поэтому крайне затруднительна, и никто еще не пытался выполнить задачу разыскивания оригиналов для более поздних курантов XVII в.

3 В РГАДА имеются четыре выпуска франкоязычных газет за 1693 г. и пять за 1698 г.; см. [35, c. $209 ; 218]$.

${ }^{4}$ Барон Шлейниц (нем. Hans Christian Freiherr von Schleinitz, годы жизни 1661-1747). В 1711 г. вступил в русскую службу; первым его местом назначения был Ганновер (с июля 1711 г.). См.: [32, S. 566; 33].

${ }^{5}$ Барон фон Шак (Bertram Freiherr von Schack, годы жизни 1679-1728), замещавший князя Бориса Куракина, русского резидента в Лондоне, в период 1713-1717 гг. См.: [32, s. 448, 566].

${ }^{6}$ В документах о принесении присяги 1720 г. Шевиус упоминается среди лютеран; см. [21, стб. 1765]. Впрочем, его сын Христиан (Christian Ferdinand, 1732-1788) также служил в Коллегии, сохраняя лютеранство; см.: [32, S. 443, 566; 33].

${ }^{7}$ Вкратце об этой газете и о сохранившихся в России выпусках см.: [15, с. 97-98].

8 Экземпляры хранятся в библиотеке РГАДА и в Российской государственной библиотеке.

${ }^{9} \kappa н(u)$ гъ - вычеркнуто.

10 греческую - вычеркнуто.

11 Слово кодекс встречается в русских текстах XVIII столетия, однако Словарь русского языка XVIII века приводит для него лишь очень узкое значение - 'собрание древнеримских законов' Самая старая фиксация датируется 1718 годом; см.: [25, с. 79].

12 Поскольку эта заметка все-таки имеет значение в связи с немецко-русскими контактами, приведем газетное опровержение здесь: «Was man übrigens vor einiger Zeit debitiren wollen/ als ob Ihro Czaarische Majestät die sämtlichen Rußischen Stände nach Petersburg kommen zu lassen/ und denenselben dero künfftigen Nachfolger/ welchen seine Majestät bereits schrifftlich ernennet/ und solche Schrifft ins Archive legen lassen/ öffentlich bekannt zu machen/ und zu declariren/gesonnen gewesen seyn solten/ wird nunmehro ungegründet befunden.»

13 О сохранившихся в России выпусках кенигсбергской газеты см. [15, с. 99].

${ }^{14}$ Слово кавалерия зафиксировано с 1698 г. См.: [24, c. 187].

15 А. А. Малышев отводит особую роль в распространении экзотизмов «Вестям-Курантам», 
«Ведомостям», а позднее «Примечаниям»к «Санкт-Петербургским Ведомостям»; см. [18].

${ }^{16}$ В [2]-Нижняя Эльва (4 раза).

17 Изучавший их А. А. Малышев отметил, что «единственным русскоязычным сотрудником “Примечаний”, практически безошибочно понимавшим все тонкости переводимого им текста, был М.В. Ломоносов» (см. [16, с. 160]).

\section{СПИСОК ЛИТЕРАТУРЫ}

1. Вести-Куранты 1656 г., 1660-1662 гг., 1664 1670 гг.: Русские тексты. Ч. 1 / изд. подгот. В. Г. Демьяновым при участии И. А. Корнилаевой ; завершение работы над изд. и подгот к печати: Е. А. Подшивалова, С. М. Шамин ; под ред. А. М. Молдована и Ингрид Майер. - М. : Рукописные памятники Древней Руси, 2009. - 856 с.

2. Вести-Куранты 1671-1672 гг. / изд. подгот. И. Майер, С. М. Шамин, А. В. Кузнецова, И. А. Корнилаева, В. Б. Крысько при участии Е. В. Амановой ; под ред. В. Б. Крысько и Ингрид Майер. - М. : Азбуковник, 2017. - $806 \mathrm{c}$.

3. Гуськов, А. Г. Великое посольство Петра I. Источниковедческое исследование / А. Г. Гуськов. М. : Ин-т рос. истории РАН, 2005. -400 c.

4. Зерцалов, А. Н. О Немецких школах в Москве в первой четверти XVIII в. (1701-1715 гг.) : Документы московских архивов, собранные действительными членами А. Н. Зерцаловым и С. А. Белокуровым / А. Н. Зерцалов, С. А. Белокуров // ЧОИДР. 1907. - Кн. 1. - C. 1-244.

5. Куранты 1724 г. // АВПРИ.-Ф. 11.-Оп. 11/1. 1724 г. - Д. 54.

6. Куранты 1724 г. // АВПРИ. -Ф. 11.-Оп. 11/1. 1724 г. - Д. 55.

7. Куранты 1725 г. // АВПРИ.-Ф. 11.-Оп. 11/1. 1725 г.-Д. 62.

8. Куранты 1726 г. // АВПРИ. -Ф. 11.-Оп. 11/1. 1726 г. - Д. 90.

9. Куранты 1727 г. // АВПРИ. -Ф. 11.-Оп. 11/1. 1727 г. - Д. 139. Д. 97.

10. Куранты 1728 г. // РГАДА. -Ф. 155. - Оп. 2. -

11. Куранты 1729 г. // АВПРИ. -Ф. 11.-Оп. 11/1. 1729 г. - Д. 186.

12. Куранты 1730 г. // АВПРИ.-Ф. 11.-Оп. 11/4. 1730 г. - Д. 1-4.

13. Куранты 1731 г. // АВПРИ.-Ф. 11.-Оп. 11/4. 1731 г. - Д. 5-6.

14. Майер, И. Вести-Куранты, 1656 г., 1660 1662 гг., 1664-1670 гг. Ч. 2. Иностранные оригиналы к русским текстам / И. Майер. - М. : Языки славянских культур, 2008. - 700 с.

15. Майер, И. Обзоры иностранной прессы в Коллегии иностранных дел в последние годы прав- ления Петра I / И. Майер, С. М. Шамин // Российская история. - 2011. - № 5. - С. 91-112.

16. Малышев, А. А. «Примечания» к «СанктПетербургским Ведомостям» как источник картотеки «Словаря русского языка XVIII века» / А. А. Малышев // Acta Linguistica Petropolitana : Труды института лингвистических исследований. 2012. - Т. 8, № 3. -С. 159-170.

17. Малышев, А. А. Внутритекстовые толкования лексики в немецком и русском текстах «Примечаний к Санкт-Петербургским Ведомостям» / А. А. Малышев // Acta Linguistica Petropolitana : Труды института лингвистических исследований. 2013. - T. 9, № 2. - С. 393-420.

18. Малышев, А. А. Экзотизмы в «Примечаниях к “Санкт-Петербургским Ведомостям"» / А. А. Малышев // Медиатекст как полиинтенциональная система. - СПб. : Институт «Высшая школа журналистики и массовых коммуникаций» федерального государственного бюджетного образовательного учреждения высшего профессионального образования «Санкт-Петербургский государственный университет», 2012. - С. 69-74.

19. Материалы и оригиналы Ведомостей 1702 1727 гг. / В. А. Погорелов. - М. : Синод. тип., 1903. $103 \mathrm{c}$.

20. Николаев, С. И. Литературная культура Петровской эпохи / С. И. Николаев. - СПб. : Дмитрий Буланин, 1996. - 152 с.

21. Поленов, Д. О присяге иноземцев, принятых в русскую службу при Петре Великом / Д. Поленов // Русский архив. - 1869. - Вып. 11. Стб. 1729-1766.

22. Словарь русского языка XI-XVII вв. Вып. 7. - М. : Наука, 1980. - 404 с.

23. Словарь русского языка XVIII века. Вып. 8. - СПб. : Наука, 1995. - 256 с.

24. Словарь русского языка XVIII века. Вып. 9. - СПб. : Наука, 1997. - 270 с.

25. Словарь русского языка XVIII века. Вып. 10. - СПб. : Наука, 1998. - 256 с.

26. Словарь русского языка XVIII века. Вып. 12. - СПб. : Наука, 2001. - 253 с.

27. Словарь русского языка XVIII века. Вып. 14. - СПб. : Наука, 2004. - 280 с.

28. Шамин, С. М. О неизвестной работе Афанасия Скиады (1724 г.) / С. М. Шамин // Пятые чтения памяти профессора Николая Федоровича Каптерева. Россия и православный Восток: новые исследования по материалам из архивов и музейных собраний (Москва, 30-31 окт. 2007 г.). - М. : Ин-т всеобщей истории РАН, 2007. - С. 199-202.

29. Шамин, С. М. Куранты XVII столетия: Европейская пресса в России и возникновение русской периодической печати / С. М. Шамин. - М. ; СПб. : Альянс-Архео, 2011.-348 с. 
30. Шамин, С. М. Россия после Петра I: реакция на преобразования в области языка (по материалам Коллегии иностранных дел) / С. М. Шамин // Русский язык и литература во времени и пространстве : сб. науч. ст. и докл. : К 45-летию Государственного института русского языка имени А. С. Пушкина. -М. : Гос. ин-т рус. языка им. А. С. Пушкина, 2011.-С. 180-188.

31. Шамин, С. М. Кусок глины в сердце Мазарини. Петр II, Остерман и «куриозные» куранты 1729 года / С. М. Шамин// Родина. - 2012. - № 8. - С. 72-74.

32. Amburger, E. Geschichte der Behördenorganisation Rußlands von Peter dem Großen bis 1917 / Erik Amburger. - Leiden : Brill, 1966. - 622 S. (Studien zur Geschichte Osteuropas, 0081-7317;10).

33. Erik-Amburger-Datenbank. - Electronic text data. - Mode of access: http://dokumente.iosregensburg.de/amburger/?id=56909. - Title from screen .

34. KöniglichePreußische Fama, 1724 г. // АВПРИ. Ф. 11.-Оп. 11/1. 1724 г. - Д. 51

35. Maier, I. Niederländische Zeitungen ("Couranten") des 17. Jahrhunderts im Russischen Staatsarchiv für alteAkten (RGADA), Moskau / I. Maier // Gutenberg-Jahrbuch. - 2004. - № 79. - S. 191-218.

36. Reichs Post Reuter, 1724 г. // АВПРИ. Ф. 11. - Оп. 11/1. 1724 г. - Д. 50.

37. Schiada, A. Arcana Bibliothecae Synodalis et typographicae Moscvensis sacra, tribus catalogis codicum manuscriptorum graecorum, superiore anno, Moscvae retecta ab Athanasio Schiada / A. Schiada. - Lipsiae [Leipzig]: Denuo luci publicae exposita accurante $\mathrm{m}$. Joanne Erhardo Kappio. Apud J. F. Gleditschii, 1724. -46 p.

\section{REFERENCES}

1. Moldovan A.M., Maier I., eds. Vesti-Kuranty 1656 g., 1660-1662 gg., 1664-1670 gg.: Russkie teksty. Ch. 1 [Vesti-Kuranty 1656, 1660-1662, 16641670: Russian Texts. Part 1]. Moscow, Rukopisnye pamyatniki Drevney Rusi, 2009. 856 p.

2. Krysko V.B., Maier I., eds. Vesti-Kuranty 1671-1672 gg. [Vesti-Kuranty 1671-1672]. Moscow, Azbukovnik Publ., 2017. 806 p.

3. Guskov A.G. Velikoe posolstvo Petra I. Istochnikovedcheskoe issledovanie [Great Embassy of Peter the Great. Source Study]. Moscow, Institut rossiyskoy istorii RAN, 2005. $400 \mathrm{p}$.

4. Zertsalov A.N., Belokurov S.A. O Nemetskikh shkolakh v Moskve v pervoy chetverti XVIII v. (17011715 gg.). Dokumenty moskovskikh arkhivov, sobrannye deystvitelnymi chlenami A. N. Zertsalovym i S. A. Belokurovym [About the German Schools in Moscow in the First Quarter of the $18^{\text {th }}$ Century (17011715). The Documents of the Moscow Archives Collected by Active Members A.N. Zertsalov and S.A. Belokurov]. CHOIDR, 1907, Book 1, pp. 1-244.
5. Kuranty 1724. AVPRI, F. 11, Op. 11/1, D. 54.

6. Kuranty 1724. AVPRI, F. 11, Op. 11/1, D. 55.

7. Kuranty 1725. AVPRI, F. 11, Op. 11/1, D. 62.

8. Kuranty 1726. AVPRI, F. 11, Op. 11/1, D. 90.

9. Kuranty 1727. AVPRI, F. 11, Op. 11/1, D. 139.

10. Kuranty 1728. RGADA, F. 155, Op. 2, D. 97.

11. Kuranty 1729. AVPRI, F. 11, Op. 11/1, D. 186.

12. Kuranty 1730. AVPRI, F. 11, Op. 11/4, D. 1-4.

13. Kuranty 1731. AVPRI, F. 11, Op. 11/4, D. 5-6.

14. Majer I. Vesti-Kuranty, 1656 g., 1660$1662 \mathrm{gg}$., 1664-1670 gg. Ch. 2. Inostrannye originaly $k$ russkim tekstam [Vesti-Kuranty. 1656, 1660-1662, 1664-1670. Part 2. Foreign Originals of Russian Texts]. Moscow, Yazyki slavyanskikh kultur Publ., 2008. 700 p.

15. Maier I., Shamin S.M. Obzory inostrannoy pressy v Kollegii inostrannykh del v poslednie gody pravleniya Petra I [Reviews of Foreign Press in the Foreign Affairs Collegium in the Last Years of the Reign of Peter I]. Rossiyskaya istoriya, 2011, no. 5, pp. 91-112.

16. Malyshev A.A. «Primechaniya» k «SanktPeterburgskim Vedomostyam» kak istochnik kartoteki «Slovarya russkogo yazyka XVIII veka» [Notes to St. Petersburg Gazette as a Source of Card File of Dictionary of the Russian Language of the $18^{\text {th }}$ Century]. Acta Linguistica Petropolitana. Trudy instituta lingvisticheskikh issledovaniy, 2012, vol. 8, no. 3, pp. 159-170.

17. Malyshev A.A. Vnutritekstovye tolkovaniya leksiki v nemetskom i russkom tekstakh «Primechaniy k Sankt-Peterburgskim Vedomostyam» [Intra-Textual Interpretations of Vocabulary in German and Russian Notes to St. Petersburg Gazette]. Acta Linguistica Petropolitana. Trudy instituta lingvisticheskikh issledovaniy, 2013, vol. 9, no. 2, pp. 393-420.

18. Malyshev A.A. Ekzotizmy v «Primechaniyakh k Sankt-Peterburgskim Vedomostyam» [Exotic Words in Notes to St. Petersburg Gazette]. Mediatekst kak poliintentsionalnaya sistema [Media Text as a Polyintentional System]. Saint Petersburg, Izd-vo SPbGU, 2012, pp. 69-74.

19. Pogorelov V.A. Materialy $i$ originaly Vedomostey $1702-1727 \mathrm{gg}$. [Materials and Originals of Vedomosti (Gazette), 1702-1727]. Moscow, Sinod. tip., $1903.103 \mathrm{p}$.

20. Nikolaev S.I. Literaturnaya kultura Petrovskoy epokhi [Literary Culture of the Peter I's Age]. Saint Petersburg, Dmitriy Bulanin Publ., 1996. 152 p.

21. Polenov D. O prisyage inozemtsev, prinyatykh v russkuyu sluzhbu pri Petre Velikom [About the Oath of Foreigners Accepted into the Russian Service under Peter the Great]. Russkiy arkhiv, 1869, iss. 11, columns 1729-1766.

22. Slovar russkogo yazyka XI-XVII vv. Vyp. 7 [Dictionary of the Russian Language, $11^{\text {th }}-17^{\text {th }} \mathrm{cc}$. Iss. 7]. Moscow, Nauka Publ., 1980. 404 p. 
23. Slovar russkogo yazyka XVIII veka. Vyp. 8 [Dictionary of the Russian Language, $18^{\text {th }}$ c. Iss. 8]. Saint Petersburg, Nauka Publ., 1995. 256 p.

24. Slovar russkogo yazyka XVIII veka. Vyp. 9 [Dictionary of the Russian Language, $18^{\text {th }}$ c. Iss. 9]. Saint Petersburg, Nauka Publ., 1997. 270 p.

25. Slovar russkogo yazyka XVIII veka. Vyp. 10 [Dictionary of the Russian Language, $18^{\text {th }}$ c. Iss. 10]. Saint Petersburg, Nauka Publ., 1998. 256 p.

26. Slovar russkogo yazyka XVIII veka. Vyp. 12 [Dictionary of the Russian Language, $18^{\text {th }}$ c. Iss. 12]. Saint Petersburg, Nauka Publ., 2001. 253 p.

27. Slovar russkogo yazyka XVIII veka. Vyp. 14 [Dictionary of the Russian Language, $18^{\text {th }}$ c. Iss. 14]. Saint Petersburg, Nauka Publ., 2004. 280 p.

28. Shamin S.M. O neizvestnoy rabote Afanasiya Skiady (1724 g.) [On the Unknown Work of Athanasius Schiady (1724)]. Pyatye chteniya pamyati professora Nikolaya Fedorovicha Kaptereva. Rossiya $i$ pravoslavnyy Vostok: novye issledovaniya po materialam iz arkhivov i muzeynykh sobraniy (Moskva, 30-31 okt. 2007 g.) [Fifth Reading in the Memory of Professor Nikolay Fedorovich Kapterev. Russia and the Orthodox East: New Research on Materials from Archives and Museum Collections. (Moscow, October 30-31, 2007). Proceedings]. Moscow, Institut vseobshchey istorii RAN, 2007, pp. 199-202.

29. Shamin S.M. Kuranty XVII stoletiya: Evropeyskaya pressa $v$ Rossii $i$ vozniknovenie russkoy periodicheskoy pechati [Kuranty of the $17^{\text {th }}$ Century: European Press in Russia and the Emergence of Russian Periodicals]. Moscow; Saint Petersburg, Alyans-Arkheo Publ., 2011. 348 p.

30. Shamin S.M. Rossiya posle Petra I: reaktsiya na preobrazovaniya v oblasti yazyka (po materialam Kollegii inostrannykh del) [Russia after Peter I: Reaction to Transformations in the Field of Language (Based on the Materials of the Collegium of Foreign Affairs)]. Russkiy yazyk i literatura vo vremeni i prostranstve: Sbornik nauchnykh statey i dokladov. K 45-letiyu Gosudarstvennogo instituta russkogo yazyka imeni A. S. Pushkina [Russian Language and Literature in Time and Space: Collection of Academic Articles and Reports. To the $45^{\text {th }}$ Anniversary of the State Institute of Russian Language named after A.S. Pushkin]. Moscow, Gosudarstvennyy institut russkogo yazyka imeni A. S. Pushkina, 2011, pp. 180-188.

31. Shamin S.M. Kusok gliny v serdtse Mazarini. Petr II, Osterman i «kurioznye» kuranty 1729 goda [A Piece of Clay in the Heart of Mazarini. Peter II, Osterman and the "Curious" Chimes of 1729]. Rodina, 2012, no. 8, pp. 72-74.

32. Amburger E. Geschichte der Behördenorganisation Rußlands von Peter dem Großen bis 1917. Leiden, Brill, 1966. 622 p. (Studien zur Geschichte Osteuropas, 0081-7317; 10)

33. Erik-Amburger-Datenbank. URL: http: //dokumente.ios-regensburg.de/amburger/?id=56909.

34. Königliche Preußische Fama, 1724. AVPRI, F. 11, Op. 11/1, D. 51 .

35. Maier I. Niederländische Zeitungen ("Couranten") des 17. Jahrhunderts im Russischen Staatsarchiv für alte Akten (RGADA), Moskau. Gutenberg-Jahrbuch, 2004, no. 79, pp. 191-218.

36. Reichs Post Reuter, 1724. AVPRI, F. 11, Op. 11/1, D. 50 .

37. Schiada A. Arcana Bibliothecae Synodalis et typographicae Moscvensis sacra, tribus catalogis codicum manuscriptorum graecorum, superiore anno, Moscvae retecta ab Athanasio Schiada. Leipzig, Denuo luci publicae exposita accurante m. Joanne Erhardo Kappio. Apud J. F. Gleditschii, 1724. 46 p.

\section{Information about the Authors}

Ingrid Maier, $\mathrm{PhD}$ (Philology), Professor of Russian Language, Department of Modern Languages, Uppsala University (Sweden), Institutionen för moderna språk, Box 636, SE - 75126 Uppsala, Sverige, Sweden, Ingrid.Maier@moderna.uu.se, https://orcid.org/0000-0003-1065-9653

Stepan M. Shamin, Candidate of Sciences (History), Senior Researcher, Institute of Russian History, Russian Academy of Sciences, Dmitriya Ulyanova, 19, 117036 Moscow, Russian Federation, shaminy@yandex.ru, https://orcid.org/0000-0003-1957-6571

\section{Информация об авторах}

Ингрид Майер, доктор филологических наук, профессор русского языка, Уппсальский университет (Швеция), кафедра современных языков, Uppsala universitet, Institutionen för moderna språk, Box 636, SE - 75126 Uppsala, Sverige, Ingrid.Maier@moderna.uu.se, https://orcid.org/0000-0003-1065-9653

Степан Михайлович Шамин, кандидат исторических наук, старший научный сотрудник, Институт российской истории Российской академии наук, ул. Дмитрия Ульянова, 19, 117036 г. Москва, Российская Федерация, shaminy@yandex.ru, https://orcid.org/0000-0003-1957-6571 